\title{
Silverfish Lepisma saccharina Linnaeus (Insecta: Zygentoma: Lepismatidae) ${ }^{1}$
}

\author{
Eleanor F. Phillips and Jennifer L. Gillett-Kaufman²
}

\section{Introduction}

Silverfish is a common name used to refer to many species in the order Zygentoma. The Entomological Society of America designates the term silverfish as the official common name to only one species, however: Lepisma saccharina Linnaeus. Lepisma saccharina is a pest in urban settings (DeVries and Appel 2013). It is a voracious feeder on materials high in starches, glue, and cellulose such as paper. Lepisma saccharina is a common pest in libraries and museums where paper books and labels are abundant (Marlatt 1902). It can also be found outdoors under rocks, leaf litter, in caves, and in ant nests (Triplehorn and Johnson 2005).

\section{Distribution}

Lepisma saccharina is found worldwide, like other insects found in homes (Marlatt 1902). Lepisma saccharina are most commonly found in North America, Europe, China, Japan, and the Hawaiian Islands (Morita 1926).

\section{Description}

Silverfish are silver or pearl-gray in color with a body covered in tiny glistening scales (Richards and Davies 1977). The scales are often described as fish-like. This is how it came by the common name silverfish. Silverfish are wingless and typically $0.85 \mathrm{~cm}(0.33 \mathrm{in})$ in length, and have two long antennae (Marlatt 1902). The body is wide at the head and tapers down to the posterior end where three long appendages with bristles appear. One of these appendages continues straight back from the end of the body and the other two curve out to the left and right at almost a ninetydegree angle (Marlatt 1902) (Figure 1). If lost, silverfish can regenerate terminal filaments and antennae in two to four weeks (Morita 1926). Silverfish are nocturnal and only rarely seen in the daytime unless disturbed from their resting places (Richards and Davis 1997).

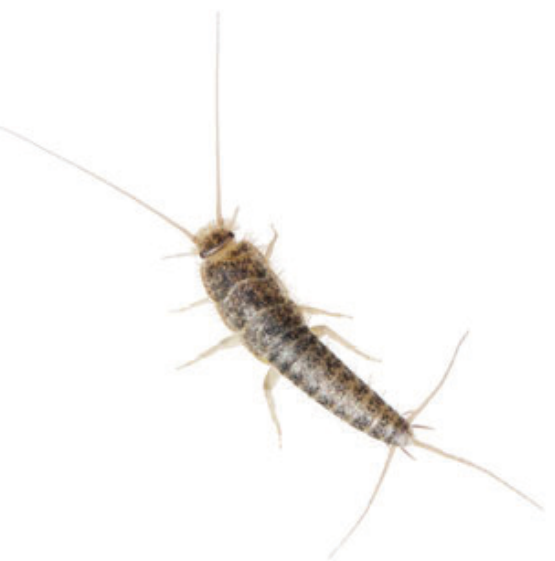

Figure 1. A silverfish, Lepisma saccharina Linnaeus. Credits: Lary Reeves, UF/IFAS

1. This document is EENY-705, one of a series of the Department of Entomology and Nematology, UF/IFAS Extension. Original publication date May 2018. Visit the EDIS website at http://edis.ifas.ufl.edu. This document is also available on the Featured Creatures website at http://entnemdept.ifas.ufl.edu/ creatures/.

2. Eleanor F. Phillips; and Jennifer L. Gillett-Kaufman, associate Extension scientist, Department of Entomology and Nematology; UF/IFAS Extension, Gainesville, FL 32611. 


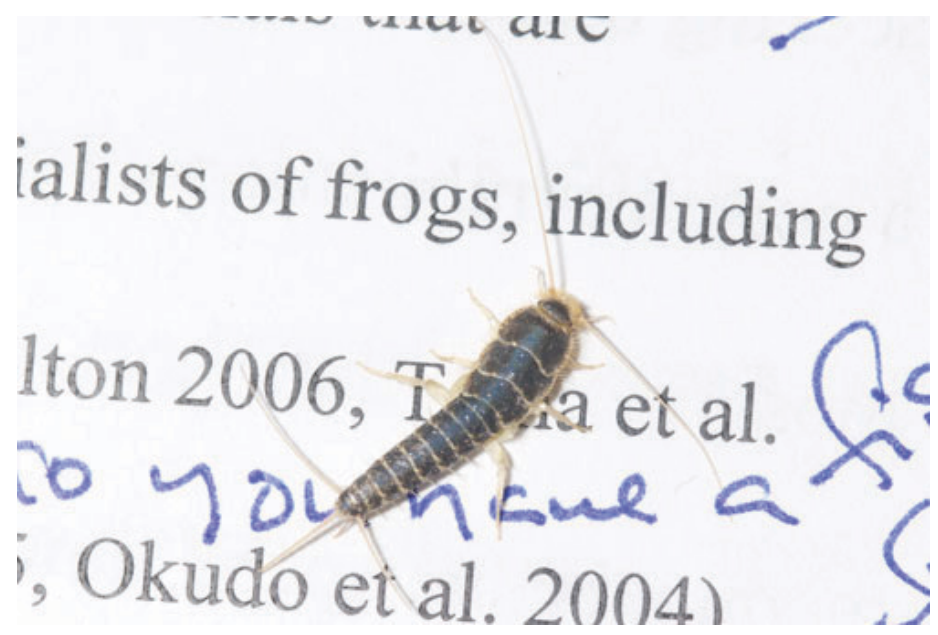

Figure 2. A silverfish, Lepisma saccharina Linnaeus. Credits: Larry Reeves, UF/IFAS

\section{Life Stages and Biology}

Silverfish are in one of the simplest, least evolved orders of insects, the Zygentoma. Many readers will remember this insect was assigned to order Thysanura, which is no longer used in the literature. Silverfish have an ametabolous life cycle. Ametabolous insect lifecycles are unique in that the adult lays eggs, and immature insects that first hatch from the eggs resemble miniature versions of the adult. Immature ametabolous insects molt a number of times, depending on the species, until they reach the adult stage and develop into sexually mature adults. Adults can continue to molt throughout their life (Morita 1926). Immature silverfish molt six to seven times until they reach their adult, sexually mature stage. Once in its adult stage, the silverfish does not have a fixed number of instars (DeVries and Appel 2013), but has been recorded molting between 25 to 66 times in a lifespan (Richards and Davies 1977). If conditions for silverfish are optimal, they may typically continue to molt during a lifespan of up to four years (Richards and Davis 1977).

The mating behavior of the silverfish begins with the male and female tapping each other with their antennae (Walker et al. 2014). The male then spins a Y-shaped silk structure and deposits its spermatophore, which contain male gametes, close to the silk structure (Walker et al. 2014). The female silverfish detects the silk spun by the male, and takes up the nearby spermatophore into her ovipositor (Walker et al. 2014). Eggs are laid in clutches of seven to twelve eggs (Morita 1926). Females typically can lay no more than 30 eggs at a time (Richards and Davis 1977). Eggs can hatch in under 20 days if the temperature is around $32^{\circ} \mathrm{C}$; however the time until hatch may take up to 40 days if temperatures are around $22^{\circ} \mathrm{C}$ (Child 2007). The time of maturation from egg to an adult is typically one year (DeVries and Appel
2013). Silverfish are capable of going for long periods of time, up to an entire year, without food (DeVries and Appel 2013).

\section{Hosts}

Silverfish have a preference for starchy materials such as paper and wood as their primary food source (DeVries and Appel 2014). Silverfish have been noted to have the strongest preference for glazed paper, which is paper that has been coated with a starch-rich layer to add glossy, smooth and shiny characteristics to paper (Morita 1926). Silverfish have been reported feeding on sugars, cellulose, linens, silk, cotton, vegetables, cereals, dried meat, dead insects, and other silverfish (DeVries and Appel 2014, Wang et al. 2006). They have been reported to eat the glue used to hold up wallpaper, curtains, carpets, book bindings, and some plush furniture coverings (Marlett 1902).

\section{Survey and Detection}

Silverfish are typically found in high humidity environments with temperatures between $22^{\circ} \mathrm{C}-27^{\circ} \mathrm{C}\left(72^{\circ} \mathrm{F}-81^{\circ} \mathrm{F}\right)$, although they are able to survive a wide range of temperatures (DeVries and Appel 2013, 2014). Silverfish are usually found indoors in concealed, temperature-controlled areas such as bathrooms, attics, and basements (DeVries and Appel 2013). Silverfish are often serious pests in commercial buildings with strict climate controls, such as museums, where they can become very problematic pests (Child 2007). When discovered or disturbed, silverfish will dart away quickly to conceal themselves, making them a challenge to catch (Marlatt 1902).

\section{Management}

Essential oil from Cryptomeria japonica (Japanese cedar) has been shown to act as a repellent and preventative control method for silverfish (Wang et al. 2006). Reducing the humidity of the silverfish's environment may reduce the silverfish population in the affected location. Some recommend freezing an object infested with silverfish to eliminate the insects (Wang et al. 2006).

Other physical measures to curb or prevent silverfish infestations include vacuuming, sealing holes and cracks in areas where silverfish are found, removing standing water and removing paper sources from cool damp environments. If infestations are heavy, chemical control measures may be used. Be sure to read all instructions on pesticide labels and follow the guidelines for physical management to prevent future infestation. 


\section{Selected References}

Child RE. 2007. Insect damage as a function of climate.

Museum Microclimates. Padfield T, Borchersen K (eds).

National Museum of Denmark pp. 57-60.

DeVries ZC, Appel AG. 2013. "Standard metabolic rates of Lepisma saccharina and Thermobia domestica: Effects of temperature and mass." Journal of Insect Physiology 59: 638-645.

DeVries ZC, Appel AG. 2014. "Effects of temperature on nutrient self-selection in the silverfish Lepisma saccharina." Physiological Entomology 39: 217-221.

Marlatt CL. 1902. The silver fish (Lepisma saccharina Linn.). United States Department of Agriculture, Division of Entomology, Circular No. 49, Second Series. Reprint Bulletin No. 4 New Series pp. 70-78.

Morita H. 1926. "Some observations on the "silverfish" (Lepisma saccharina L.) (Thys.)." Proceedings of the Hawaiian Entomological Society 2: 271-273.

Richards OW, Davies RG. 1977. Imms' General Textbook of Entomology 10th Edition Volume 2, Classification and Biology. Imms AD, Richards OW, Davies RG. (eds). New York, NY: Chapman and Hall Halsted Press Book, John Wiley \& Sons. pp. 433-443.

Triplehorn C, Johnson NF. 2005. Order Thysanura Silverfish. pp. 179-180 in Howe E, Feldmen E, and Michel L, editors. Borror and Delong's Introduction to the Study of Insects. Belmont, CA: Brooks/Cole of Thomson Learning, Inc.

Walker AA, Church JS, Woodhead AL, Sutherland TD. 2013. "Silverfish silk is formed by entanglement of randomly coiled protein chains." Insect Biochemistry and Molecular Biology 43: 572-579.

Wang S-Y, Lai W-C, Chu F-H, Lin C-T, Shen S-Y, Chang S-T. 2006. "Essential oil from the leaves of Cryptomeria japonica acts as a silverfish (Lepisma saccharina) repellent and insecticide." The Japan Wood Research Society 52: 522-526. 